KS. WOJCIECH GÓRALSKI

Wydział Prawa Kanonicznego

Uniwersytetu Kardynała Stefana Wyszyńskiego w Warszawie

ORCID: 0000-0001-6548-4120

\title{
MAŁŻONKOWIE CHRZEŚCIJAŃSCY NA WZÓR AKWILI I PRYSCYLLI DAREM BOŻYM I POTRZEBA KOŚCIOŁA. PRZEMÓWIENIE FRANCISZKA DO ROTY RZYMSKIEJ Z 25 STYCZNIA 2020 ROKU
}

Treść: Wstęp. - 1. Wędrujący małżonkowie. - bliscy innym i bezinteresowni. - 2 Czego małżonkowie chrześcijańscy powinni się uczyć od Akwili i Pryscylli. - 3. Zachęta do kontynuowania dzieła świętych małżonków starożytnego Kościoła. - Uwagi końcowe.

\section{Wstęp}

W dniu 25 stycznia 2020 roku papież Franciszek przyjął na dorocznej audiencji w Sali Klementyńskiej prałatów - audytorów Roty Rzymskiej w związku z inauguracją nowego roku sądowego. Po przemówieniu dziekana wymienionego Trybunału Apostolskiego, Pio Vito Pinto, Ojciec Święty wygłosił okolicznościową alokucję.

Tym razem tematyka przemówienia papieskiego odbiegła od podejmowanych tradycyjnie problemów związanych z kwestiami stricte kanonistycznymi odnoszącymi się najczęściej do określonych tytułów nieważności małżeństwa lub zadań sędziego w procesie nullitatis matrimonii.

Franciszek nawiązuje do swojej katechezy wygłoszonej 13 listopada 2019 roku, w której przypomina, iż św. Paweł znalazł gościnę u małżeństwa Akwili i Pryscylli (Pryski) zmuszonych przenieść się 
do Koryntu po tym, jak cesarz Klaudiusz nakazał wydalenie Żydów $($ Dz 18,2)․․ J Jak sam zaznacza, alokucja skierowana do Roty Rzymskiej ma być „dalszą refleksją nad pierwszorzędną rolą pary małżonków Akwili i Pryscylli jako wzorów życia małżeńskiego"2.

\section{Wędrujący małżonkowie - bliscy innym $\mathrm{i}$ bezinteresowni ${ }^{3}$}

Zdaniem Ojca Świętego, Kościół chcąc naśladować Jezusa, musi działać zgodnie z warunkami przez Niego potwierdzonymi: bycie w drodze, gotowość i zdecydowanie ${ }^{4}$. Z natury swojej Kościól „jest w ruchu”, nie pozostaje „spokojnie w swojej zagrodzie”, jest bardzo szeroko otwarty; jest posłany, by nieść Ewangelię na drogi i peryferie

${ }^{1}$ W katechezie tej Franciszek ukazuje nie tylko gościnność małżonków Akawili i Pryscylli, lecz również podkreśla, że ich dom w Koryncie, poza św. Pawłem, przyjął także „braci i siostry w Chrystusie”. Paweł mógł więc mówić o „zbierającym się w ich domu Kościele” (1 Kor 16,19), który staje się „domus ecclesiae”, miejscem słuchania Słowa Bożego i sprawowania Eucharystii. Gdy oboje małżonkowie, stwierdza Papież, powrócą do Rzymu, będą adresatami wspaniałej pochwały, którą Apostoł zamieszcza w liście do Rzymian: „Pozdrówcie współpracowników moich w Chrystusie Jezusie, Pryskę i Akwilę, którzy za moje życie nadstawili swe głowy i którym winienem wdzięczność nie tylko ja sam, ale i wszystkie Kościoły [nawróconych] pogan” (16,4). Franciszek zauważa, że Akwila i Pryscylla pojawiają się jako „przykład życia małżeńskiego odpowiedzialnie zaangażowanego w służbie całej wspólnoty chrześcijańskiej i przypominają nam, że dzięki wierze i zaangażowaniu w ewangelizację wielu świeckich takich jak oni, chrześcijaństwo do nas dotarło”. FRANCISZEK, Katecheza wygłoszona podczas audiencji ogólnej 13 listopada 2019 roku, https://ekai. pl/dikumeny/audeiecja-generalna - z-papiezem-franciszkiem (dostęp 28.04.2020).

2 ,Desidero ricollegarmi alla catechesi svolta nell'udienza generale di mercoledì 13 novembre 2019, offrendo oggi a voi un'ulteriore riflessione sul ruolo primario della coppia di sposi Aquila e Priscilla come modelli di vita coniugale”. Discorso del Santo Padle Francesco in occasione dell' inaugurazione dell'anno giudiziario del Tribunale della Rota Romana del 25 gennaio 2020, https://www.vatican.va/colntent/francesco/ it/speeches/2020/january/documents/papa/francesco_20200125_rota-romana.html (dostęp 30.04.2020); Zob. także Franciszek, Pan przyszedł, by szukać grzeszników. Przemówienie do członków Roty Rzymskiej, „L'Osservatore Romano” (wyd. polskie) 41 (2020), nr 2-3, s. 11.

${ }^{3}$ Śródtytuły komentarza pochodzą od jego autora.

${ }^{4}$ Zob. Franciszek, Przemówienie na „Anioł Pański” z 30.06.2019, https://ekai.pl/ dokumenty/aniol-panski - z - franciszkiem-30-czewca-2019 (dostęp; 28.04.2020). 
ludzkie i egzystencjalne; przypomina małżonków z Nowego Testamentu: Akwilę i Pryscyllę.

Wspomniana para małżeńska, stwierdza Papież, stojąca u boku św. Pawła, to para wędrowna, będąca w ciągłym ruchu. Ten model wędrujących małżonków przez wiele stuleci nie miał jednak w duszpasterstwie Kościoła własnej tożsamości ewangelizatorów. A tego właśnie potrzebowały wspólnoty parafialne, zwłaszcza miejskie, których duszpasterze nie są w stanie dotrzeć do wiernych, którzy są chrześcijanami jedynie de nomine, nie korzystają bowiem z sakramentów i za mało znają Chrystusa albo nie znają Go w ogóle.

Stwierdzając następnie, że małżonkowie Akwila i Pryscylla byli nauczycielami, których znamionowała bliskość i bezinteresowność, Mówca dodaje, że dokonując reformy procesu małżeńskiego (w Liście apostolskim Mitis Iudex z 15 sierpnia 2015 roku), położył nacisk na owe „dwie perły”: bliskość i bezinteresowność. Podobnie św. Paweł znalazł u wymienionych małżonków chrześcijańskich sposób bycia blisko tych, którzy są daleko i umiłował ich, żyjąc z nimi ponad rok w Koryncie, gdyż byli małżonkami-nauczycielami bezinteresowności . Te dwie niezwykłe wartości: bliskość i bezinteresowność, wyznaje Franciszek, bardzo często wyzwalają w nim lęk przed osądem Bożym: czy osądzając, byłem blisko serca ludzi? Czy w osądzaniu otworzyłem serce na bezinteresowność, czy byłem pochłonięty interesami handlowymi? ${ }^{8}$

\footnotetext{
${ }^{5}$ Franciszek, Pan przyszedł, by szukać grzeszników..., s. 11.

${ }^{6}$ Papież Franciszer, List apostolski motu proprio „Mitis Iudex Dominus Iesus”, reformujacy kanony Kodeksu Prawa Kanonicznego dotyczace spraw o orzeczenie nieważności małżeństwa. List apostolski motu proprio „Mitis et misericors Jesus”, reformujący kanony Kodeksu Kanonów Kościołów Wschodnich dotyczące spraw o orzeczenie nieważności (tekst łacińsko-polski), Tarnów 2015, Wprowadzenie, n. VI (bliskość między sędzią i wiernymi oraz bezinteresowność wyrażająca się w dążeniu do tego, by proces był bezpłatny); Franciszek, Pan przyszedł, by szukać grzeszników..., s. 11.

${ }^{7}$ Franciszek, Pan przyszedt, by szukać grzeszników..., s. 11.

${ }^{8}$ Tamże, s. 11-12.
} 


\section{Czego małżonkowie chrześcijańscy powinni się uczyć od Akwili i Pryscylli}

Następca Benedykta XVI uznaje, że małżonkowie chrześcijańscy powinni uczyć się od pary małżeńskiej zaprzyjaźnionej ze św. Pawłem, jak rozmiłować się w Chrystusie i być blisko rodzin, które często są pozbawione światła wiary nie z powodu ich subiektywnej winy, ale dlatego, że zostały pozostawione na marginesie naszego duszpasterstwa - duszpasterstwa elitarnego, które zapomina o ludzie9. Ojciec Święty wyraża przy tym gorące pragnienie, by jego przemówienie „nie pozostało jedynie symfonią słów, ale pobudziło, z jednej strony pasterzy: biskupów, proboszczów do starania się, by umiłować, tak jak Apostoł Paweł, pary małżonków, będących pokornymi misjonarzami, gotowymi docierać na te place i do tych budynków naszych metropolii, do których światło Ewangelii i głos Jezusa nie docierają i nie przenikają, a z drugiej strony, małżonków chrześcijańskich, którzy mieliby odwagę wyrywać ze snu, jak to czynili Akwila i Pryscylla, zdolnych do działania, nie mówimy, że w sposób autonomiczny, ale z pewnością pełnych odwagi, żeby budzić z odrętwienia i ze snu pasterzy, być może zbyt zastałych albo blokowanych przez filozofię małego kręgu doskonałych. Pan przyszedł, by szukać grzeszników, nie ludzi doskonałych"10.

Przywołując fragment encykliki Pawła VI Ecclesiam suam z 6 sierpnia 1964 roku, papież Franciszek stwierdza, że zanim zacznie się mówić, trzeba najpierw wsłuchać się w głos, co więcej, w serce

\footnotetext{
${ }^{9}$ Tamże, s. 12.

${ }^{10}$ "Quanto vorrei che questo discorso non restasse soltanto una sinfonia di parole, ma spingesse, da una parte, i pastori, i vescovi, i parroci a cercare di amare, come fece l'Apostolo Paolo, coppie di sposi quali missionari umili e disponibili a raggiungere quelle piazze e quei palazzi delle nostre metropoli, nelle quali la luce del Vangelo e la voce di Gesù non giunge e non penetra. E, d'altra parte, sposi cristiani che abbiano l'ardire di scuotere il sonno, come fecero Aquila e Priscilla, capaci di essere agenti non diciamo in modo autonomo, ma certo carichi di coraggio fino al punto di svegliare dal torpore e dal sonno i pastori, forse troppo fermi o bloccati dalla filosofia del piccolo circolo dei perfetti. Il Signore è venuto a cercare i peccatori, non i perfetti". Tamże.
} 
człowieka; zrozumieć go i na ile to możliwe szanować go, a w tym, gdzie na to zasługuje, wspierać go ${ }^{11}$.

We wsłuchiwaniu się w serce człowieka, zdaniem Franciszka, chodzi o to, co zalecał biskupom włoskim 19 maja 2014 roku, a mianowicie, by wsłuchali się w owczarnię, byli blisko ludzi i starali się nauczyć ich języka, podchodzić do każdego z miłością, towarzyszyć ludziom „W ich nocach” samotności, niepokojów i porażek ${ }^{12}$.

Dawny arcybiskup Buenos Aires podkreśla następnie, że „święte pary chrześcijańskie" nie są rezultatem ludzkiej przedsiębiorczości pasterzy, lecz dziełem Ducha Świętego. Natomiast do pasterzy należy ich oświecanie i sprawianie, by były widoczne, oraz uczynienie ich źródłem nowej umiejętności przeżywania małżeństwa chrześcijańskiego, a także chronienie ich, żeby nie uległy ideologiom. Pary te, niewątpliwie ożywiane przez Ducha Świętego, powinny być gotowe do wyjścia poza siebie i otworzenia się na innych, do życia w bliskości, do przyjęcia stylu życia razem, który przemienia każdą relację międzyosobową w doświadczenie braterskie ${ }^{13}$. Wypowiadając te słowa, Franciszek odnosi je do posługi duszpasterskiej w katechumenacie przedmałżeńskim i postmałżeńskim, którą to posługę powinny prowadzić i rozwijać właśnie owe pary małżeńskie ${ }^{14}$.

W trosce o właściwie wykonywane zadania przez te ostatnie, $\mathrm{Pa}$ pież Argentyńczyk wyraża potrzebę czuwania, by nie uległy one niebezpieczeństwu partykularyzmu, ograniczając się do aktywności realizowanej jedynie w wybranych grupach, wszak trzeba się otworzyć na powszechność zbawienia ${ }^{15}$.

\footnotetext{
${ }^{11}$ Paulus VI, Litterae encyclicae „Ecclesiam suam” (06.08.1964), AAS 56 (1964), n. 90; Franciszek, Pan przyszedł, by szukać grzeszników..., s. 12.

${ }^{12}$ Francesco, Allocuzione alla Conferennza dei Vescovi Italiami (19.05.2014), AAS 107 (2015), s. 1139; Franciszek, Pan przyszedt, by szukać grzeszników..., s. 12.

${ }^{13}$ Papież nawiązał tutaj do swojej katechezy z 16 października 2019 roku. Zob. FranciszeK, Katecheza podczas audiencji ogólnej z 16 października 2019 roku, https://www.radiomaryja.pl/multimedia/audiencja - generalna-ojca-swietego-franciszka-16-10-2019 (dostęp 29.04.2020).

${ }^{14}$ Franciszek, Pan przyszedł, by szukać grzeszników..., s. 12.

${ }^{15}$ Por. Franciszek, Katecheza podczas audiencji ogólnej z 16 października 2019 roku...
} 
Nawiązując do swojej Adhortacji apostolskiej Amoris laetltia z 19 marca 2016 roku, Ojciec Święty zauważa, iż znacząca jest obecność w Kościele ruchów i stowarzyszeń, które nie zaniedbują formacji małżonków chrześcijańskich. Szczególnym miejscem eklezjalnym głoszenia i dawania świadectwa jest parafia, gdyż to tutaj żyją już chrześcijańscy małżonkowie, godni oświecać, którzy mogą być aktywnymi świadkami piękna oraz miłości małżeńskiej i rodzinnej ${ }^{16}$.

W dalszym ciągu alokucji Papież wyraża przekonanie, że działalność apostolska parafii w Kościele „rozświetla się” przez obecność małżonków, takich jak opisani przez św. Łukasza w Dziejach Apostolskich; ,oni nigdy nie trwają w bezruchu, lecz - przeciwnie - ,zawsze są w ruchu, oczywiście z potomstwem, zgodnie z tym, co nam zostało przekazane przez ikonografię Kościołów Wschodnich"17. Zadaniem duszpasterzy jest troska o to, by z pomocą Ducha Świętego urzeczywistniało się owo ,zbawcze głoszenie” ze strony par małżeńskich, „które często są już gotowe, ale nie wezwane”, a są takie ${ }^{18}$.

Papież Franciszek ponownie podkreśla, że Kościół potrzebuje dzisiaj „małżonków w ruchu”, i to wszędzie. Najbardziej jednak, dodaje, chrześcijaństwo zapuściło swoje korzenie w pierwszych czterech stuleciach, poczynając od katakumb, na co zwrócił uwagę Paweł VI zamykając Sobór Watykański II, kiedy to udał się do katakumb Domitylli. Powiedział wówczas: „Tutaj chrześcijaństwo zapuściło swoje korzenie w ubóstwie, przy ostracyzmie ustanowionych władz, znosząc cierpienia niesprawiedliwych i krwawych prześladowań; Tutaj Kościół był ogołocony z wszelkiej ludzkiej władzy, był ubogi, był pokorny, był pobożny, był uciskany, był heroiczny. Tutaj prymat Ducha, o którym mówi nam Ewangelia, zyskał sobie mroczne, niemal tajemnicze, ale

\footnotetext{
${ }^{16}$ Francesco, „Amoris laetitia”. Esortazione apostolica sull'amore nella familia, Città del Vaticano-Cinisello Balsamo 2016. Tekst polski: FrAnCiszek, Posynodalna Adhortacja Apostolska „Amoris laetitia” - o miłości w rodzinie, Kraków 2016, nn. 126-130; Fr Anciszek, Pan przyszedł, by szukać grzeszników..., s. 12.

${ }^{17}$, „...] mai fermi, sempre in movimento, certamente con prole, secondo quanto ci è tramandato dall'iconografia delle Chiese orientali". Franciszer, Pan przyszedt, by szukać grzeszników..., s. 12.

${ }^{18}$ Tamże.
} 
niezłomne potwierdzenie, swoje niezrównane świadectwo, swoje męczeństwo"19.

Moc, która czyni pary małżonków chrześcijańskich, kontynuuje Franciszek, dusza i forma ewangelizacji, zależy od wzywania Ducha Świętego, co powinno dokonywać się w parafii, jako „terytorium prawo-zbawczym”, „domem pośród domów” i „rodziną rodzin”. To tutaj powstaje „łańcuch małżonków pełnych entuzjazmu i rozmiłowanych w swej wierze w Zmartwychwstałego, zdolnych do nowej rewolucji czułości miłości, jak Akwila i Pryscylla, nigdy nie usatysfakcjonowanych ani nie skupionych na sobie samych"20.

Okazując fascynację w stosunku do aktywności wymienionej pary małżonków, Franciszkowi, jak sam zaznacza, nasuwa się myśl, że nie mieli oni czasu, by okazywać zmęczenie. Tak też zresztą charakteryzują ich św. Paweł i św. Łukasz, dla których byli towarzyszami niemal nieodzownymi, „właśnie dlatego, że nie byli wezwani przez Pawła, ale wzbudzeni przez Ducha Jezusa" ${ }^{21}$. Na tym właśnie opierała się ich apostolska godność małżonków chrześcijańskich: „to Duch ich wzbudził". Tak też bywa, gdy do jakiegoś miejsca przybywa misjonarz - „tam jest już Duch Święty, który go oczekuje”22.

\footnotetext{
19 „Qui il cristianesimo affondò le sue radici nella povertà, nell'ostracismo dei poteri costituiti, nella sofferenza di ingiuste e sanguinose persecuzioni; qui la Chiesa fu spoglia di ogni umano potere, fu povera, fu umile, fu pia, fu oppressa, fu eroica. Qui il primato dello Spirito di cui ci parla il Vangelo ebbe la sua oscura, quasi misteriosa, ma invitta affermazione, la sua testimonianza incomparabile, il suo martirio". Il Concilio Vaticano II, t. 2, Città del Vaticano 1965, s. 520.

${ }^{20}$ Franciszek, Pan przyszedł, by szukać grzeszników..., s. 12. Papież powołał się w tym fragmencie na swoją homilię wygłoszoną w Domu św. Marty 9 maja 2016 roku (https://opoka.org.pl/biblioteka/W/WP/franciszek_i/homilie/swmarta_09052016 html; dostęp:28.04.2020) oraz na homilię wygłoszoną w Albano 21 września 2019 roku (https://wkai.pl/dokumenty/homilia-papieza-franciszka-albano-21-wrzesnia-2015 html; dostęp: 28.04.2020).

${ }^{21}$ „Così, in effetti, sono descritti da Paolo e da Luca, per i quali furono compagni quasi indispensabili, proprio perché non chiamati da Paolo ma suscitati dallo Spirito di Gesù”. Franciszek, Pan przyszedł, by szukać grzeszników..., s. 13.

${ }^{22}$ Tamże.
} 
Podziw Mówcy dla wielkości Akwili i Pryscylli idzie w parze z ubolewaniem, że te „święte postaci” pokrywało tak długie milczenie wczesnego Kościoła ${ }^{23}$.

\section{Zachęta do kontynuowania dzieła świętych małżonków starożytnego Kościoła}

Głębokie pochylenie się Następcy św. Piotra nad niezwykłymi postaciami Akwili i Pryscylli, niezmordowanych ewangelizatorów, skłoniło go do skierowania usilnej zachęty braci biskupów i wszystkich pasterzy, ,,by wskazywali owych małżonków pierwotnego Kościoła jako wiernych i świetlanych towarzyszy pasterzy; jako wsparcie współczesne oraz przykład tego, jak małżonkowie chrześcijańscy, młodzi i starsi, mogą czynić małżeństwo chrześcijańskie zawsze płodnym w dzieci w Chrystusie"24. Wszyscy powinni być przekonani, a nawet pewni, że takie pary małżeńskie są darem Bożym, lecz nie przez zasługi kogokolwiek, ale przez fakt, że są owocem działania Ducha Świętego, który nigdy nie opuszcza Kościoła. Duch Święty oczekuje zapału ze strony pasterzy, ,aby nie zostało zgaszone światło, jakie te pary szerzą na peryferiach świata"25.

Papież Bergoglio apeluje do pasterzy, by pozwolili Duchowi Świętemu odnawiać wyznawców Kościoła, a także by godzili się na „Kościół nielicznych, niemal ciesząc się z bycia jedynie odosobnionym zaczynem, pozbawieni owej zdolności par małżonków z Nowego Testamentu, które mnożyły się w pokorze i w posłuszeństwie Duchowi, który oświeca i potrafi uczynić zbawczą naszą ludzką działalność,

\footnotetext{
${ }^{23}$ Tamże.

${ }^{24}$ „Invito e sollecito i fratelli Vescovi e i Pastori tutti a indicare questi santi sposi della prima Chiesa come compagni fedeli e luminosi dei Pastori di allora; come sostegno, oggi, ed esempio di come gli sposi cristiani, giovani e anziani, possano rendere il matrimonio cristiano sempre fecondo di figli in Cristo". Tamże.

${ }^{25}$, ,[...] affinché non venga spenta la luce che queste coppie diffondono nelle periferie del mondo (cfr Gaudium et spes, 4-10)". Tamże. Franciszek odwołał się tutaj do Konstytucji duszpasterskiej Gaudium et spes Soboru Watykańskiego II, nn. 4-10.
} 
a także naszą nędzę"26. Wszak trzeba być przekonanym, że Kościół nie wzrasta za sprawą prozelityzmu, ale przez przyciąganie, a przyciąga tylko prawdziwe świadectwo.

Nawiązując raz jeszcze do postaci Akwili i Pryscylli, Ojciec Święty stwierdza, że jakkolwiek nie wiemy, czy ponieśli śmierć męczeńską, to jednak nie ulega wątpliwości, że dla współczesnych małżonków są oni znakiem męczeństwa, przynajmniej duchowego, „czyli świadkami zdolnymi być zaczynem, który dodaje się do mąki, być zaczynem w masie, który obumiera, żeby stać się masą" ${ }^{27}$.

Zwracając się do audytorów rotalnych, Franciszek stwierdza: „Mrok wiary i pustynia wiary, które wasze decyzje - poczynając już od jakichś dwudziestu lat - ujawniały jako możliwą okoliczność przyczynową nieważności zgody małżeńskiej, skłaniają mnie ${ }^{28}$, podobnie jak mojego poprzednika, Benedykta XVI ${ }^{29}$, do poważnej i naglącej zachęty synów Kościoła epoki, w której żyjemy, do tego, by wszyscy i poszczególni czuli się wezwani do przekazania przyszłości piękna rodziny chrześcijańskiej" ${ }^{\prime 30}$.

${ }^{26}$ „, Lasciate, perciò, che rinnovi lo Spirito a non rassegnarsi a una Chiesa di pochi, quasi a gradire di rimanere solo lievito isolato, privi di quella capacità degli sposi del Nuovo Testamento di moltiplicarsi nell'umiltà e nell'obbedienza allo Spirito. Lo Spirito che illumina ed è capace di rendere salvifica la nostra attività umana e la nostra stessa povertà”. FrANCISzEK, Pan przyszedł, by szukać grzeszników..., s. 13.

${ }^{27}$, Di Aquila e Priscilla non sappiamo se morirono martiri, ma di certo essi sono, per i nostri sposi di oggi, segno del martirio, almeno spirituale, cioè testimoni capaci di essere lievito che va nella farina, di essere lievito nella massa, che muore per diventare la massa”. Tamże. Papież przywołał tutaj swoje przemówienie wygłoszone do stowarzyszeń rodzin katolickich w Europie w dniu 1 czerwca 2017 roku (https://kodr.pl/wp-content/uploads/2017/02/38-nr-Biuletynu-Krajowego-O\%C\%\%9 Osrodka-Duszpasterstwa-Rodzin-Czerwiec,pdf; dostęp: 29.04.2020).

${ }^{28}$ Ojciec Święty wskazał tutaj swoje Motu proprio Mitis Iudex (Ratio procedendi, art. 14) oraz swoje przemówienia do Roty Rzymskiej z 23 stycznia 2015 roku, AAS 107(2015), s. 182-185) i z 22 stycznia 2016 roku, AAS 108 (2016), s. 136-139).

${ }^{29}$ Franciszek wskazał tutaj przemówienie Benedykta XVI d Roty Rzymskiej z 22 stycznia 2011 roku, AAS 103 (2011), s. 108-113.

${ }^{30}$ „Cari Giudici della Rota Romana, il buio della fede o il deserto della fede che le vostre decisioni, a partire già da un ventennio, hanno denunciato come possibile circostanza causale della nullità del consenso, offrono a me, come già al mio 
Mówca wyraża przekonanie, że Kościół na całej ziemi potrzebuje par małżonków na wzór Akwili i Pryscylli, mówiących i żyjących z autorytetem chrztu, który to autorytet nie polega na „rządzeniu i podnoszeniu głosu", ale na byciu konsekwentnym, byciu świadkiem, a przez to byciu towarzyszami drogi na ścieżkach Pana ${ }^{31}$.

Podziękowanie Bogu za to, że także dzisiaj daje dzieciom Kościoła odwagę i światło, by powracały do początków wiary i odnajdywały gorliwość małżonków Akwili i Pryscylli, tak by byli rozpoznawani w każdym małżeństwie w Chrystusie Jezusie, kończy alokucję papieskąa ${ }^{32}$.

\section{Uwagi końcowe}

Jak już wyżej wspomniano, tradycyjne przemówienie papieskie do Roty Rzymskiej z 2020 roku nie zostało poświęcone określonej kwestii ściśle kanonistycznej, związanej zazwyczaj z procesem o nieważność małżeństwa (w aspekcie prawa materialnego lub procesowego). Tym razem Ojciec Święty podjął temat natury bardziej pastoralnej, dotyczący bowiem potrzeby kształtowania dojrzałych duchowo małżonków chrześcijańskich, którzy by wspierali duszpasterzy w dziele ewangelizacji rodziny.

„Bohaterami” alokucji Franciszkowej są niezwykli małżonkowie epoki starożytnej Kościoła: Akwila i Pryscylla, wierni towarzysze św. Pawła Apostoła, stanowiący wzorową pod każdym względem parę małżeńską; ich imiona padają w przemówieniu aż siedem razy, nie licząc sformułowań „zastępczych”.

predecessore Benedetto XVI (cfr Allocuzioni alla Rota Romana 23 gennaio 2015 e 22 gennaio 2016; 22 gennaio 2011; cfr art. 14 Ratio procedendi del Motu proprio Mitis Iudex Dominus Iesus), il motivo di un grave e pressante invito ai figli della Chiesa nell'epoca che viviamo, a sentirsi tutti e singoli chiamati a consegnare al futuro la bellezza della famiglia cristiana". FranciszeK, Pan przyszedt, by szukać grzeszników..., s. 13.

${ }^{31}$ Papież odwołał się tutaj do własnej homilii wygłoszonej w Domu św. Marty 14stycznia 2020 roku (http://messadelpapa.com/omelia-del-14-gennaio-2020-vangelo-e-parola-del giorno (dostęp30.04.2020).

${ }^{32}$ Franciszek, Pan przyszedł, by szukać grzeszników..., s. 13. 
Owi małżonkowie stojący u boku św. Pawła zostali ukazani jako para mobilna, trwająca w ustawicznym ruchu, a więc wychodząca naprzeciw potrzebom ówczesnych wspólnot chrześcijańskich, a przy tym bliska ludziom i bezinteresowna. Te przymioty cechujące Akwilę i Pryscyllę Franciszek bardzo eksponuje, dostrzegając potrzebę wypracowywania ich przez współczesnych małżonków zaangażowanych $\mathrm{w}$ niesienie pomocy rodzinom, często pozbawionym światła wiary. Jednocześnie przestrzega przed elitarnym traktowaniem tej posługi, która powinna obejmować lud (uwaga ta niewątpliwie jest aktualna i dzisiaj, wszak niekiedy wśród liderów ruchów i wspólnot kościelnych można zetknąć się z taką tendencją). Nie bez znaczenia jest również i ta dyrektywa, w myśl której we wspomnianej posłudze nie wolno ulegać partykularyzmowi, który ogranicza aktywność par małżeńskich do wybranych grup, tymczasem wezwanie do zbawienia ma charakter powszechny. Rozmiłowanie w Chrystusie i bliskie trwanie przy rodzinach to, zdaniem Papieża, istotne wymogi skutecznego apostolstwa „rodzinnego”.

Swoje zatroskanie o instytucje małżeństwa i rodziny Następca Benedykta XVI wyraża również w gorącym pragnieniu zmobilizowania duszpasterzy do bycia blisko małżonków, a także „wyszukiwania” par małżeńskich, które byłyby gotowe do angażowania się w duszpasterstwo rodzin. Jedno i drugie zadanie uznać należy za bardzo istotne w obszarze tegoż duszpasterstwa.

Trafna wydaje się również zachęta papieska skierowana do małżonków chrześcijańskich, by - za przykładem Akwili i Pryscylli umiejętnie aktywizowali duszpasterzy, niejednokrotnie blokowanych „przez filozofię małego kręgu doskonałych”. A gdy mowa o pasterzach, nie sposób nie dostrzec jakże słusznej sugestii dotyczącej potrzeby (i umiejętności) wsłuchiwania się przez nich „w serce człowieka”, tylko bowiem wówczas ich posługa przyniesie oczekiwane przez wiernych rezultaty.

Na zwrócenie uwagi zasługuje przekonanie Franciszka, że święte pary małżeńskie są dziełem Ducha Świętego, nie zaś efektem aktywności pasterzy. Ci ostatni natomiast powinni takich małżonków eksponować oraz chronić przed ideologiami, co może mieć duże 
znaczenie w prowadzeniu katechumenatu przedmałżeńskiego i katechumenatu małżonków.

Katechumenatowi przedmałżeńskiemu, dodajmy, papież Franciszek dużo uwagi poświęcił w Adhortacji apostolskiej Amoris laetitia (nn. 205-216), stwierdzając m.in., że towarzyszenie narzeczonym na drodze ich miłości jest dobrem wspólnot chrześcijańskich, które takie towarzyszenie podejmują ${ }^{33}$. Wydaje się, że właśnie w tychże wspólnotach duszpasterze mogą „wyszukiwać” odpowiednie pary małżeńskie gotowe do owego towarzyszenia przyszłym małżonkom. Co się tyczy zaś katechumenatu małżonków, to w powołanym dokumencie zwraca się szczególną uwagę na towarzyszenie im w pierwszych latach wspólnoty życia ${ }^{34}$. To tutaj pada m.in. doniosła dyrektywa papieska: „Całe duszpasterstwo rodzinne musi być kształtowane wewnętrznie i formować członków Kościoła domowego przez modlitewną i kościelną lekturę Pisma Świętego"35.

W prowadzeniu duszpasterstwa, tak narzeczonych, jak i rodzin, zauważa w swoim przemówieniu Franciszek, niemałą rolę mogą odgrywać działające w parafiach ruchy i stowarzyszenia. I dodaje, że właśnie parafia jest właściwym miejscem realizowania tegoż duszpasterstwa.

Jak należy sądzić, nawiązywanie przez Ojca Świętego raz po raz do historycznych postaci Akwili i Pryscylli, niezmordowanych misjonarzy rodzin, powinno głęboko zapaść w serce zarówno powołanym do posługi duszpasterskiej biskupom i kapłanom, jak i natchnionym przez Ducha Świętego gorliwym parom małżonków, które niewątpliwi są darem Bożym i potrzebą Kościoła.

\footnotetext{
${ }^{33}$ Francesco, „Amoris laetitia”..., n. 207.

${ }^{34}$ Tamże, nn. 217-230.

35 Tamże, n. 227.
} 


\section{Christian spouses modeled on Aquila and Priscilla, God's gift and the need of the Church. Francis' speech to the Roman Rota of January 25, 2020}

On January 25, 2020, Pope Francis received an annual audience of judges and other employees of the Roman Rota in connection with the inauguration of the new judicial year. After the speech of the dean mentioned, the Holy Father gave an occasional allocation. This time, the subjects of the papal speech departed from the traditional problems associated with strictly canonist issues, most often referring to specific titles of marriage annulment or tasks of a judge in a marriage annulment process.

The Holy Father took up the topic of a more pastoral nature, concerning the need to shape spiritually mature Christian spouses who would support pastors in the work of evangelizing the family.

The „heroes” of Francis allocation are the extraordinary spouses of the ancient Church era: Aquila and Priscilla, faithful companions of Saint. Paul the Apostle, constituting an exemplary marriage couple.

Francis fervent desire to mobilize priests to be close to their spouses and to "search" for married couples who would be ready to engage in family ministry. Both tasks should be considered very important in the field of this pastoral work.

SŁowA KLuCzowe: Akwila i Pryscylla; pary małżeńskie; duszpasterstwo narzeczonych i małżonków

Keywords: Aquila and Priscilla; married couples; pastoral care of engaged couples and spouses

\section{Nota o AUTORze}

Ks. PROF. DR HAB. WoJCIECH GóralsKi - kierownik Zakładu Kościelnego Prawa Rodzinnego na Wydziale Prawa Kanonicznego UKSW, założyciel i redaktor naczelny kwartalnika „Ius Matrimoniale”, wiceprzewodniczący Stowarzyszenia Kanonistów Polskich, sędzia w Sądzie Biskupim w Płocku. 